Article

\title{
Granulated Blast-Furnace Slag and Coal Fly Ash Ternary Portland Cements Optimization
}

\author{
Rosa Abnelia Rivera ${ }^{1}$, Miguel Ángel Sanjuán ${ }^{2, * \mathbb{D}}$ and Domingo Alfonso Martín ${ }^{3}$ \\ 1 Department of Cement Chemical Testing, LOEMCO, Universidad Politécnica de Madrid (UPM), \\ 28906 Madrid, Spain; rosa.rcornelio@alumnos.upm.es \\ 2 Civil Engineering School, Universidad Politécnica de Madrid, 28040 Madrid, Spain \\ 3 Mine and Energy Engineering School, Universidad Politécnica de Madrid (UPM), 28003 Madrid, Spain; \\ domingoalfonso.martin@upm.es \\ * Correspondence: masanjuan@ieca.es; Tel.: +34-628-62-3817
}

Received: 11 June 2020; Accepted: 15 July 2020; Published: 17 July 2020

check for updates

\begin{abstract}
Granulated blast-furnace slag (GBFS) and coal fly ash (CFA) are two well-known constituents in Portland cements. Ternary Portland cements (GBFS-CFA-K) provide environmental advantages by reducing Portland cement clinker $(\mathrm{K})$ production and, therefore, promote lower $\mathrm{CO}_{2}$ emissions. Nevertheless, both of them cause a delay in the compressive strength gain. Given that, the early compressive strength for both constituents is low, but they improve the compressive strength at medium and later ages as consequence of the pozzolanic reaction. In this paper, a full factorial design with two levels was developed for the mortar compressive strength estimation at 2, 7 and 28 days. Mortar prisms made with $25 \%$ and $40 \%$ of granulated blast-furnace slag (GBFS) and/or coal fly ash (CFA) were tested. The effects of the interaction between GBFS and CFA on the compressive strength development of ternary Portland cement mortars were reported. Results show that the contribution of both cement constituents to the ternary mortar mix reduces the compressive strength for all the tested ages. Nevertheless, the finer the GBFS, the better ternary cement performance was achieved, showing that the synergistic effect is more effective when the finer GBFS is used, probably due to a more adequate particle size distribution. Finally, a relationship between compressive strength, fineness, GBFS content and CFA content was found for each age.
\end{abstract}

Keywords: sustainable cement-based materials; eco-friendly construction and building materials; ternary cements; coal fly ash; granulated blast-furnace slag; compressive strength; synergy

\section{Introduction}

Ternary cement is one that contains Portland cement clinker and two other cement constituents in Portland cement, blended either at the cement mill or blending device. The use of ternary cements has been proposed to decrease the environmental impact of Portland cement production, mainly because these cements need smaller amounts of clinker and, therefore, a portion of $\mathrm{CO}_{2}$ emissions are avoided. Their utilization is being enhanced in order to reach the target of lowering greenhouse gas emissions (GHG), carbon dioxide in particular, to 50-55\% below 1990 levels in 2030, according to the roadmap for moving to a competitive low carbon economy in 2050 [1].

The global production of Portland cement was reported to be 4.65 billion tons in 2016 [2] and is predicted to surpass 7 billion tons in 2050. Such cement production demands a significant amount of natural resources and energy, accounting for higher share of $\mathrm{CO}_{2}$ emission. Currently, the production of one ton of Portland cement emits about 0.87 tons of carbon dioxide [3]. This value would be reduced significantly by using ternary cements. 
In particular, clinker replacement is considered as one of the main reductions levers for the cement industry [4]. Nowadays, clinker is mostly replaced with industrial wastes such as ground granulated blast-furnace slag and coal fly ash or natural rocks as limestone and natural pozzolans. Also, other constituents include silica fume, artificial pozzolans and so on.

Ternary cements usage is a good solution to reduce the environmental impact of the cement industry and is promoted nowadays though the European standard for common cements. According to the European standard EN 197-1 [5], the ternary cements included are named composite cements, CEM V, which contains $40-64 \%$ of clinker, $18-30 \%$ of blast-furnace slag (S) and $18-30 \%$ of coal fly ash (V) and/or natural pozzolan $(\mathrm{P})$ and/or calcined pozzolan $(\mathrm{Q})$ in the case of CEM V/A. For the composite cement CEM V/B, these ranges are $20-38 \%, 31-50 \%$ and $31-50 \%$, respectively. This standard is currently under revision. The new prEN 197-5 [6] includes a series of novel ternary cements with blast-furnace slag (S) or coal fly ash (V) mixed with limestone (L, LL) up to $20 \%$. In these cases, the clinker amount will be lowered to a range from 35\% to $49 \%$ (CEM VI). Other materials in combination with Portland clinker, such as silica fume (D) or calcareous fly ash (W) are not currently standardized in ternary mixes. The novelty comes from the increase of usage in Portland cements.

The share of non-CEM I cements production in the EU (CEMBUREAU countries) has risen by $13 \%$ to $75 \%$ between 1994 and 2010 [7], calculated with regards to all EU cement production. This fact is a result of the International Energy Agency (IEA) and World Business Council for Sustainable (WBCSD) recommendations for promoting the development of new cements [8]. Given that, the CEN Technical Report CEN/TR 16912, published in May 2016, provides the guidelines for a procedure to support the European standardization of new cements. To even better stimulate the use of ternary cements, it would be necessary to assess their suitability for use for cement-based materials.

Blast-furnace slag is characterized by its pozzolanicity and hydraulicity when finely ground, which contributes to its durability and long-term compressive strength [9], while an optimum dosage of coal fly ash also has a beneficial effect on the early age compressive strength due to its early pozzolanic reactivity. Ternary cements with ground blast-furnace slag, coal fly ash and Portland cement clinker should have particularly interesting outcomes after combining their early age and later age properties' development and their synergetic effects. Ternary cements have been studied by several researchers by combining limestone with blast-furnace slag [9-14], coal fly ash [15,16], natural pozzolan [17] or metakaolin [18]. Some other researchers reported improvements in compressive strength in ternary systems containing different amounts of silica fume and coal fly ash [19-22] or blast-furnace slag [23]. In particular, ternary cements made with blast-furnace slag and coal fly ash have also been studied. Kashani et al. [24] modeled the yield stress of ternary cement-slag-fly ash pastes based on particle size distribution data; Douglas and Pouskouleli [25] and Wang and Chen [26] developed prediction models of compressive strength of mortars made with cement-GGBFS-fly ash ternary mixtures. High strength concrete applications of ternary mixtures were explored by Erdem and Kirca [27]. In all these studies, the synergies of ternary binders in hydration reactions were more or less evident [28]. Quaternary mixes of fly ash, blast furnace slag with silica fume [29] or limestone [30] represent a step forward on this issue. In addition to mechanical performance studies, the durability of these new binders has been studied. In particular, Alonso et al. [31] have studied the corrosion of steel of concrete embedded in these binders. The higher the addition content, the lower the $\mathrm{pH}$ of the pore solution is. Accordingly, the higher risk of corrosion could be expected in ternary and quaternary cements.

According to Tan et al. [32] and Li and Zhao [33], Portland cement:GBFS:CFA ternary systems provide higher mechanical strength at all ages than the corresponding binary systems, especially when CFA and GBFS are finely ground $\left(6000 \mathrm{~cm}^{2} / \mathrm{g}\right)$ [32]. In contrast, Jeong et al. [34] did not found any significant differences in the mechanical performance of $40 \%: 40 \%: 20 \%$ and $40 \%: 50 \%: 20 \%$ Portland cement:GBFS:CFA ternary systems.

In addition, Fernández et al. [28] reported that the Portland cement chemical composition strongly influences the synergistic effect between GBFS and CFA in ternary cementitious systems. As a result, CFA reactivity is improved when GBFS has a high $\mathrm{Al}_{2} \mathrm{O}_{3}$ content in agreement with other 
researchers [32,33]. They also found that monocarboaluminate is formed at early ages when the Portland cement presents high amounts of alumina, leading to a compressive strength decrease. On the other hand, hydrotalcite, monocarboaluminate and hemicarbonate are produced at later ages instead of monosulfate when low aluminate and alkali cements are used in the ternary system. In general, low aluminate and alkali amounts in the Portland cements negatively affects the early compressive strength of the ternary cement made with GBFS and CFA. Recently, the effect of quaternary cementitious systems containing limestone began being developed [35,36].

Optimization for ternary cement constituent proportions has been performed by several authors $[9,13,22,23,26]$. However, only a few studies dealing with the optimization for ternary cement constituent proportions of clinker-blast-furnace slag-coal fly ash have been reported [26]. In most of the cases, the final result in the ternary cement has been obtained as a consequence of the combination of the individual properties of all the constituents and their synergy.

The aim of this study is to assess the compressive strength performance of mortars made with newly developed ternary cements combining a Portland cement (CEM I 42.5 R) with two different ground granulated blast-furnace slags and one coal fly ash, in comparison with a reference mortar made only with CEM I 42.5 R [5]. Ground granulated blast-furnace slags had high or low fineness to evaluate its effect in the mechanical performance. Optimization of these ternary Portland cements has been made with a statistical factorial design of experiments. The main effects of these ternary cements on two, seven- and 28-days compressive strength are presented.

\section{Experimental}

\subsection{Materials}

A Portland cement CEM I 42.5 R according to the European standard EN 197-1 [5] and two cement constituents (ground granulated blast-furnace slag and coal siliceous fly ash supplied by Cementos Tudela Veguín, S. A. (Aboño, Spain) were used to prepare the ternary cements in the laboratory. They have been characterized at the chemical and physical levels. Their chemical properties are given in Table 1. Chemical analyses of $\mathrm{SiO}_{2}, \mathrm{Al}_{2} \mathrm{O}_{3}, \mathrm{Fe}_{2} \mathrm{O}_{3}, \mathrm{CaO}, \mathrm{MgO}, \mathrm{SO}_{3}, \mathrm{Na}_{2} \mathrm{O}, \mathrm{K} 2 \mathrm{O}$, loss on ignition (LOI), insoluble residue (IR) and $\mathrm{Cl}^{-}$were performed according to the European standard EN 196-2. The free lime in the cement and coal fly ash was $1.31 \%$ and $0.5 \%$, respectively. With regard to the GBFS, the reactive $\mathrm{CaO}$ and reactive silica were $3.84 \%$ and $44.78 \%$, respectively. The ground granulated blast-furnace slag was ground in a ball mill to achieve two different fineness levels: $3489 \mathrm{~cm}^{2} / \mathrm{g}$ and $4630 \mathrm{~cm}^{2} / \mathrm{g}$. Cement and coal fly ash fineness was $3246 \mathrm{~cm}^{2} / \mathrm{g}$ and $3772 \mathrm{~cm}^{2} / \mathrm{g}$, respectively, determined according to EN 196-6. Cement and coal fly ash density was $3.12 \mathrm{~g} / \mathrm{cm}^{3}$ and $2.4 \mathrm{~g} / \mathrm{cm}^{3}$, respectively.

Table 1. Chemical compositions of cements determined according to EN 196-2 (\%).

\begin{tabular}{|c|c|c|c|c|c|c|c|c|c|c|c|}
\hline Cement & $\mathrm{SiO}_{2}$ & $\mathrm{Al}_{2} \mathrm{O}_{3}$ & $\mathrm{Fe}_{2} \mathrm{O}_{3}$ & $\mathrm{CaO}$ & $\mathrm{MgO}$ & $\mathrm{SO}_{3}$ & $\mathrm{Na}_{2} \mathrm{O}$ & $\mathrm{K}_{2} \mathrm{O}$ & LOI & $\mathrm{IR}^{1}$ & $\mathrm{Cl}^{-}$ \\
\hline CEM I $42.5 \mathrm{R}$ & 20.51 & 4.30 & 3.01 & 60.38 & 3.61 & 3.14 & 0.16 & 0.81 & 2.78 & 1.44 & 0.05 \\
\hline Blast-furnace slag & 35.96 & 10.61 & 0.40 & 42.89 & 7.10 & 2.02 & 0.30 & 0.46 & 0.00 & - & - \\
\hline Coal fly ash & 53.79 & 19.54 & 10.20 & 4.44 & 1.83 & 0.84 & 2.03 & 1.83 & 1.73 & 17.41 & - \\
\hline
\end{tabular}

${ }^{1}$ Insoluble residue determined by the $\mathrm{Na}_{2} \mathrm{CO}_{3}$ method (European standard EN 196-2).

Blast-furnace slag and coal fly ash meet the requirements from standard EN 197-1regarding the characteristics of the cement constituents.

\subsection{Mix Design and Mortar Preparation}

This study focuses on Portland cement clinker (K) —blast-furnace slag (S) — coal fly ash (V)—based ternary cements (K-V-S). The composite cements were prepared by mixing CEM I $42.5 \mathrm{R}$ with these cement constituents (two ground granulated blast-furnace slags and one coal siliceous fly ash) and the different proportions of these studied ternary mixes are illustrated in the ternary diagrams shown in 
Figure 1. Blast-furnace slag and coal siliceous fly ash content was $25 \%$ or $40 \%$, therefore, the CEM I amount was $20 \%, 35 \%$ or $50 \%$ (Table 2). CEM I $42.5 \mathrm{R}$ was also used as a reference $(100 \%)$.

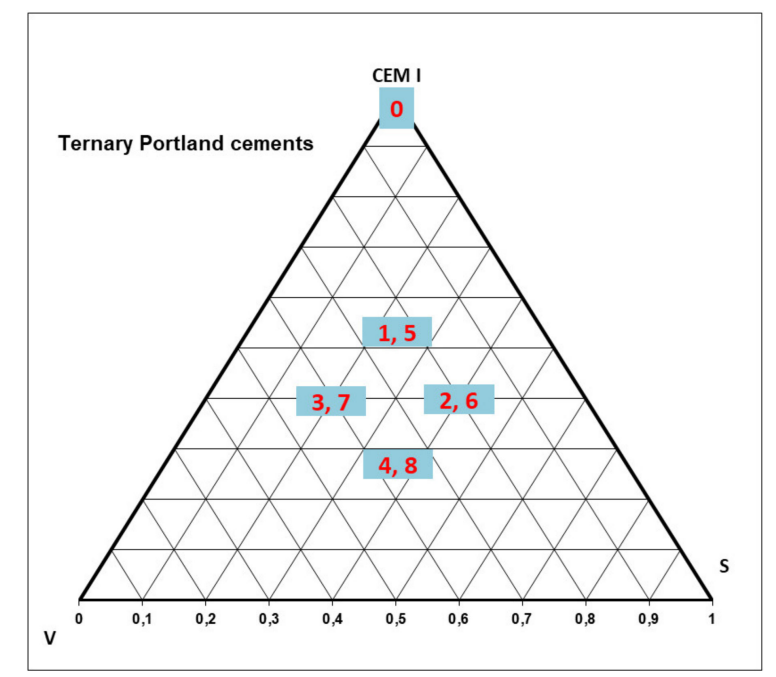

Figure 1. Ternary cements CEM I-ground granulated blast-furnace slags-coal siliceous fly ash.

Table 2. Codes and proportions of the ternary cements.

\begin{tabular}{|c|c|c|c|c|}
\hline Code & Cement (\%) & $\mathrm{S}(\%)$ & $\mathrm{V}(\%)$ & $\mathrm{S}$-Fineness $\left(\mathrm{cm}^{2} / \mathrm{g}\right)$ \\
\hline SA0VA0 & 100 & 0 & 0 & - \\
\hline SA25VA25 & 50 & 25 & 25 & 3489 \\
\hline SA40VA25 & 35 & 40 & 25 & 3489 \\
\hline SA25VA40 & 35 & 25 & 40 & 3489 \\
\hline SA40VA40 & 20 & 40 & 40 & 3489 \\
\hline SB25VA25 & 50 & 25 & 25 & 4630 \\
\hline SB40VA25 & 35 & 40 & 25 & 4630 \\
\hline SB25VA40 & 35 & 25 & 40 & 4630 \\
\hline SB40VA40 & 20 & 40 & 40 & 4630 \\
\hline
\end{tabular}

These raw materials were mixed in the proportions shown in Table 2 to obtain eight different ternary cements. The first column shows the mixture code, which is composed of two letters SA or SB depending on the fineness of the slag given in the fifth column, followed by the content of the slag ( 25 or $40 \%$ ). The next two letters, VA, followed by the numbers indicate the fly ash content ( 25 or $40 \%)$. Then, mortar prismatic specimens $(40 \times 40 \times 160 \mathrm{~mm})$ were made with distilled water and CEN sand according to the European standard EN 196-1. The cement/sand ratio was 1/3 and water/cement ratio was 0.50 . The specimens were demolded $24 \pm 1 \mathrm{~h}$ after casting and stored for two, seven or 28 days under water saturated in lime. They were kept in different containers to avoid any interference between the potential ion diffusion of the tested mixtures.

\subsection{Compressive Strength}

The specimens were tested for compressive strength at two, seven or 28 according to the European standard EN 196-1. The average value recorded from six hemi-specimens was taken.

\section{Results}

\subsection{Compressive Strength}

The mechanical properties of the ternary cements were determined and nearly all of them meet the requirements from the European standard EN 197-1 regarding 28-days compressive strength, as shown 
in Figure 2. The failure mode for all the mortar mixtures revealed that there is no difference between the tested specimens.

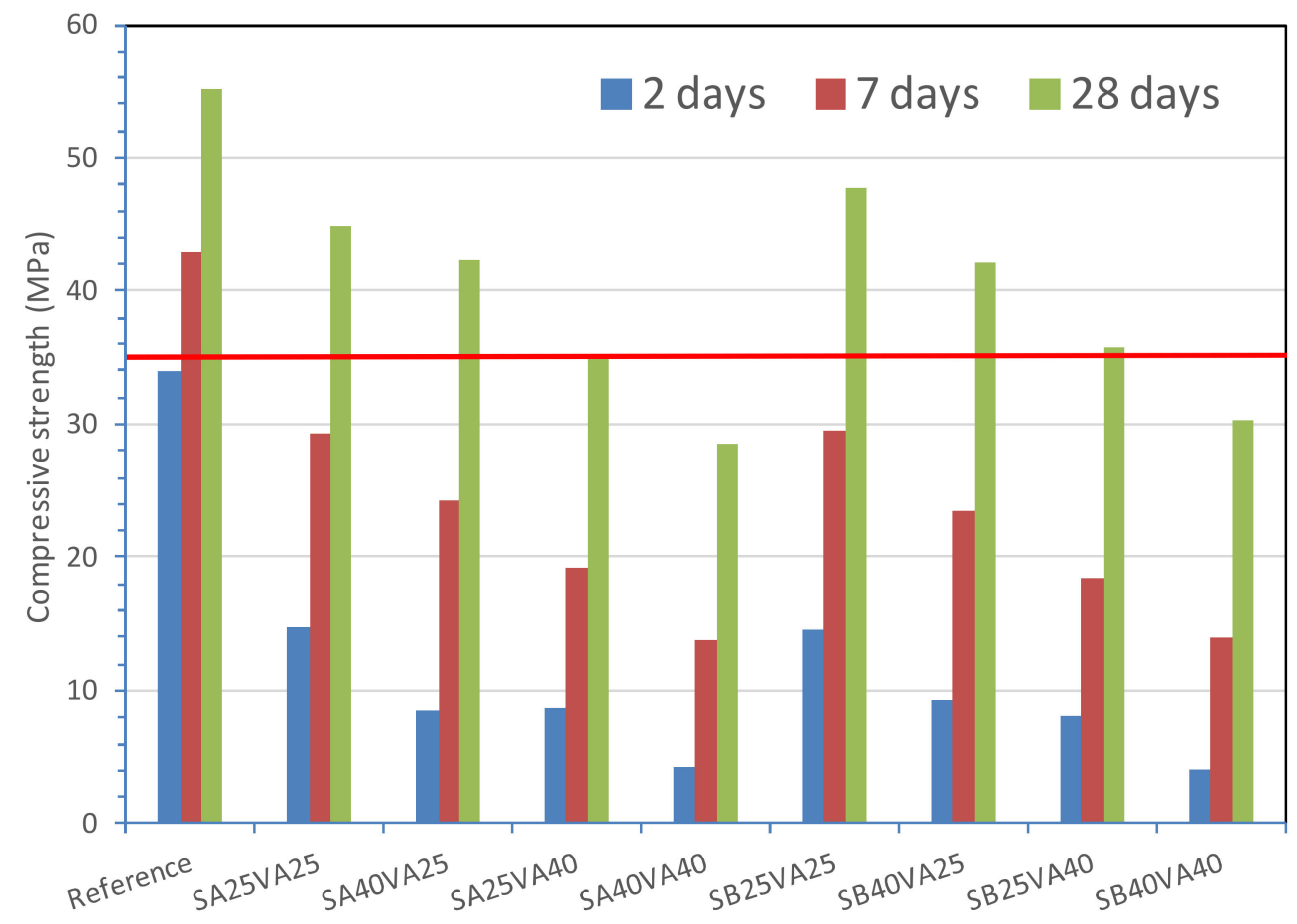

Figure 2. Compressive strength at 2, 7 and 28 days. The red line is at $32.5 \mathrm{MPa}$.

Ternary cements with $40 \%$ GBFS and 40\% CFA (SA40VA40 and SB40VA40) do not reach the minimum compressive strength for the $32.5 \mathrm{~N}$ compressive class (16 MPa at 7 days and $32.5 \mathrm{MPa}$ at 28 days), independently of the slag fineness. Therefore, these types of ternary cements are not recommended for structural applications [37]. However, it could be used in non-structural usages. All the rest meet the standardized requirements for the $32.5 \mathrm{~N}$ compressive class. Conversely, only ternary cements with $25 \%$ granulated blast-furnace slag and 25\% coal fly ash (SA25VA25 and SB25VA25) reach the minimum compressive strength for the $32.5 \mathrm{R}$ compressive class (10 MPa at 2 days and $32.5 \mathrm{MPa}$ at 28 days).

At early ages (2 and 7 days) SA provides similar compressive strengths than SB (Figure 2). However, at later ages, ( 28 days) this similarity is apparently ended by the faster pozzolanic reaction development in the finer binder [17].

The higher fineness of granulated blast-furnace slag (GBFS) increases the 28 days compressive strength of ternary cements containing about $25-40 \%$ GBFS and $20-40 \%$ coal fly ash (CFA), but by lower amounts than Portland cement alone. A synergistic effect in ternary cements is more effective in finer GBFS, as it notably improved the mechanical strength at 28 days, probably due to a denser microstructure. Summing up, the finer the granulated blast-furnace slag (GBFS), the better its performance at older ages.

\subsection{Full Factorial Design}

A full factorial design in two levels, named high and low and designated as +1 and -1 , respectively, with three factors was utilized. This full factorial design with three factors, each at two levels, has eight runs (Table 3). 
Table 3. Experimental setup.

\begin{tabular}{|c|c|c|c|c|c|c|c|c|c|c|}
\hline \multirow[t]{2}{*}{ Run } & \multirow[t]{2}{*}{ Experimental Point } & \multicolumn{3}{|c|}{ Experimental Matrix } & \multicolumn{3}{|c|}{ Experimental Plan } & \multicolumn{3}{|c|}{ Response (Compressive Strength) } \\
\hline & & $\mathrm{X} 1$ & $\mathrm{X} 2$ & $\mathrm{X} 3$ & $\mathrm{~S}(\%)$ & $\mathrm{V}(\%)$ & $\begin{array}{l}\text { Fineness } \\
\left(\mathrm{cm}^{2} / \mathrm{g}\right)\end{array}$ & $\begin{array}{l}\text { R2D } \\
(\mathrm{MPa})\end{array}$ & $\begin{array}{c}\text { R7D } \\
(\mathrm{MPa})\end{array}$ & $\begin{array}{l}\text { R28D } \\
(\mathrm{MPa})\end{array}$ \\
\hline 2 & y2 & + & - & - & 40 & 25 & 3489 & 8.60 & 24.30 & 42.30 \\
\hline 3 & y3 & - & + & - & 25 & 40 & 3489 & 8.70 & 19.20 & 34.90 \\
\hline 4 & y4 & + & + & - & 40 & 40 & 3489 & 4.20 & 13.80 & 28.60 \\
\hline 7 & y7 & - & + & + & 25 & 40 & 4630 & 8.20 & 18.40 & 35.70 \\
\hline \multirow[t]{2}{*}{8} & y8 & + & + & + & 40 & 40 & 4630 & 4.10 & 14.00 & 30.20 \\
\hline & & & & & & & $\begin{array}{l}\text { Grand } \\
\text { Mean }\end{array}$ & 9.05 & 21.51 & 38.30 \\
\hline
\end{tabular}

The details of the full factorial design are as follow:

- Factor X1: Blast-furnace slag, S, with levels 25\% and 40\%.

- Factor X2: Coal fly ash, V, with levels $25 \%$ and $40 \%$.

- Factor X3: Fineness $\left(3489 \mathrm{~cm}^{2} / \mathrm{g}\right.$ and $4630 \mathrm{~cm}^{2} / \mathrm{g}$ ).

- Unit: MPa.

- $\quad$ Response variable 1: Deviation from the actual 2-days compressive strength.

- $\quad$ Response variable 2: Deviation from the actual 7-days compressive strength.

- $\quad$ Response variable 3: Deviation from the actual 28-days compressive strength.

Figure 3 shows the general scheme of the full factorial experimental design for 2-days, 7-days and 28-days. In the corners, the compressive strength results are given, whereas their differences are placed along the edges of the cube.

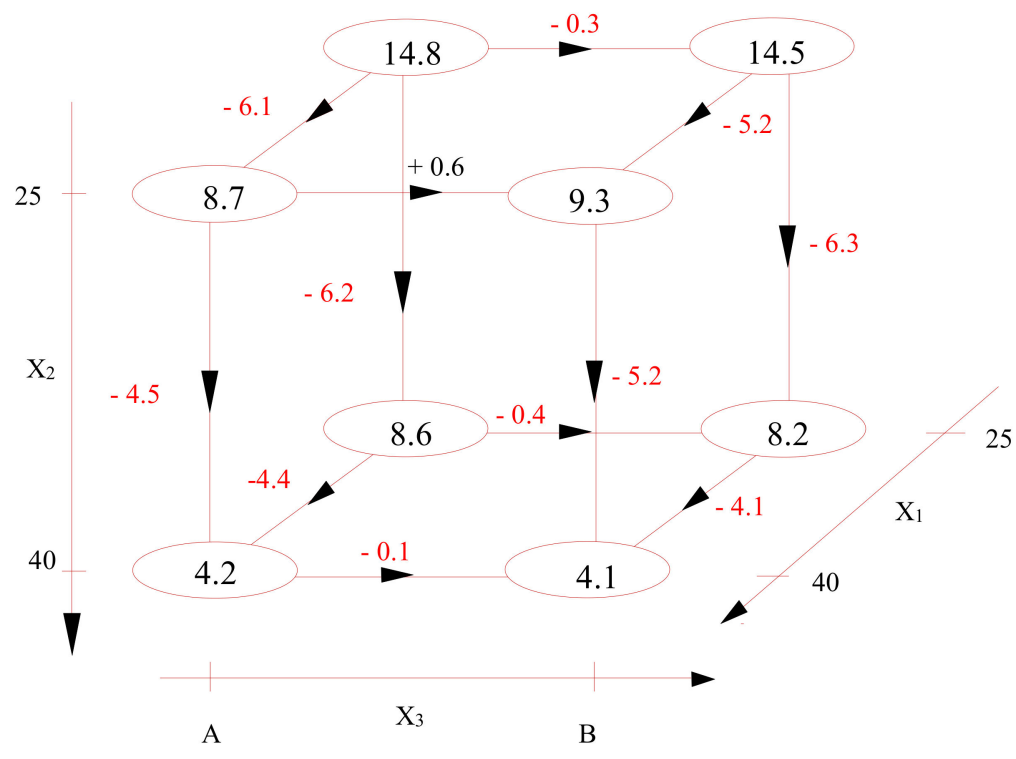

(a)

Figure 3. Cont. 


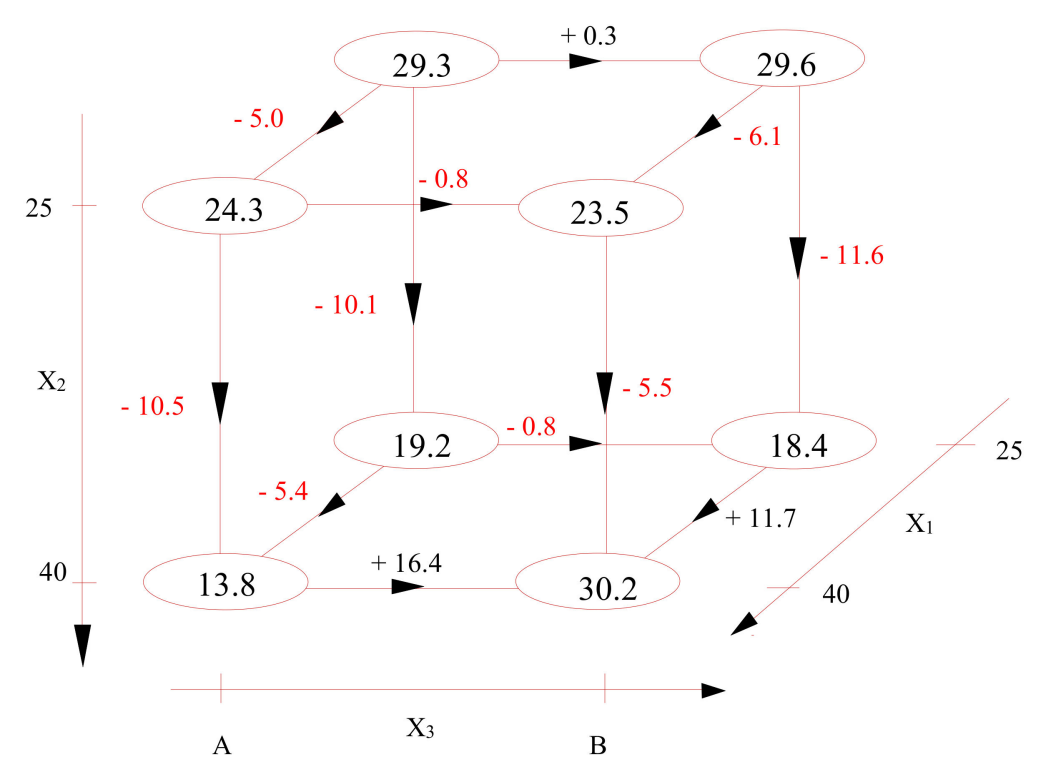

(b)

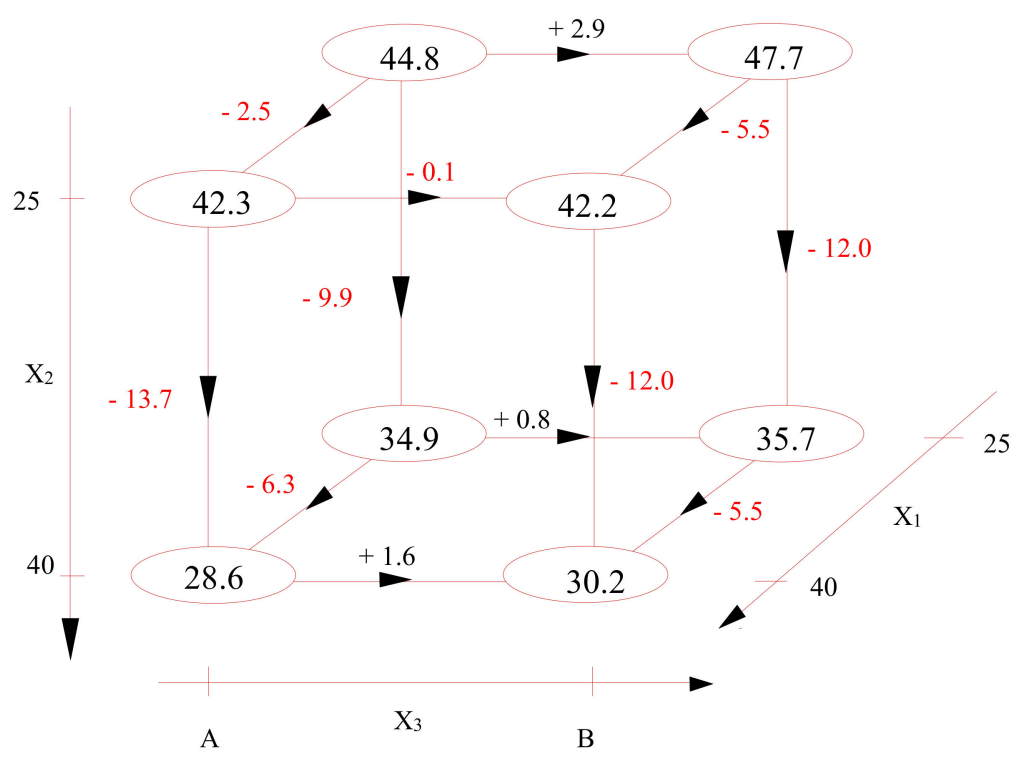

(c)

Figure 3. Scheme of the full factorial experimental design: (a) 2-days; (b) 7-days; (c) 28-days. Compressive strength results at the corners (MPa).

The minus symbol (-) in Table 3, stands for factors X1, X2 and X3 at the low level; the plus symbol (+) depicts factors $\mathrm{X} 1, \mathrm{X} 2$ and $\mathrm{X} 3$ at the high level.

The highest compressive strength at two days was found for the SA25VA25 ternary cement; seven days and 28 days were the equivalent results for the SB25VA25 ternary cement. The only difference was the ground granulated blast-furnace slag fineness. In contrast, the lowest compressive strength at two days was found in the SB40VA40 ternary cement; seven days and 28 days were the equivalent results for the SA40VA40 ternary cement. Once again, the difference between the results at early age (two days) and later ages (seven and 28 days) was attributed to the ground granulated blast-furnace slag fineness. 
In general, the higher ground granulated blast-furnace slag and coal fly ash amount, the lower compressive strength for all the tested ages. These results are in accord with other ones [9-11].

The Grand Mean or the global average of the results is 9.05, 21.51 or $38.30 \mathrm{MPa}$ at two, seven or 28 days, respectively (Table 3). The results average for X1- (i.e., factor X1 run at low level) at two days is $11.55 \mathrm{MPa}((14.80+8.70+14.50+8.20) / 4)$. Table 4 collects all the average of the results calculated for the three responses considered in this paper. All the factors run at a low level, $\mathrm{X} 1-, \mathrm{X} 2-$ and X3-, showed higher mean compressive strength than the factors run at a high level, $\mathrm{X} 1+, \mathrm{X} 2+$ and $\mathrm{X} 3+$. Nevertheless, the difference between the high and the low-level decreases from 2 to 28 days due to the effect of the pozzolanic reaction development at older ages [28].

Table 4. $\mathrm{X} 1, \mathrm{X} 2, \mathrm{X} 3$ averages, main effects and main effects squared at low and high levels (compressive strength, MPa) and Sum of Squares (SS).

\begin{tabular}{ccccccccccccccc}
\hline & & \multicolumn{3}{c}{ Average } & \multicolumn{4}{c}{ Main Effect } & \multicolumn{3}{c}{ Main Effect Squared } & \multicolumn{3}{c}{ Sum of Squares } \\
\hline Days & Level & X1 & X2 & X3 & X1 & X2 & X3 & X1 & X2 & X3 & SSA & SSB & SSC \\
\hline \multirow{2}{*}{2} & low & 11.55 & 11.80 & 9.08 & 2.50 & 2.75 & 0.03 & 6.25 & 7.56 & 0.0006 & 50 & 60.5 & 0.005 \\
& high & 6.55 & 6.30 & 9.03 & -2.50 & -2.75 & -0.03 & 6.25 & 7.56 & 0.0006 & & & \\
\multirow{2}{*}{7} & low & 24.13 & 26.68 & 21.65 & 2.61 & 5.16 & 0.14 & 2.61 & 5.16 & 0.14 & 54.6 & 213.2 & 0.151 \\
& high & 18.90 & 16.35 & 21.38 & -2.61 & -5.16 & -0.14 & -2.61 & -5.16 & -0.14 & & & \\
28 & low & 40.78 & 44.25 & 37.65 & 2.48 & 5.95 & -0.65 & 6.13 & 35.40 & 0.43 & 49.0 & 283.2 & 3.4 \\
& high & 35.83 & 32.35 & 38.95 & -2.48 & -5.95 & 0.65 & 6.13 & 35.40 & 0.43 & & & \\
\hline
\end{tabular}

The main effects or effect size were calculated subtracting the factor average from the Grand Mean (Table 4). They establish which factors have the most relevant effects on the results. Therefore, at early ages ( 2 and 7 days) the effect of the three factors is very small and it sharply increases at 28 days. Consequently, the study of the main effects is a quick and efficient tool to visualize the effect size. Finally, Table 4 shows the sum of squares (SS). For the treatment of the data and assessing the significance of each factor, based on the effect determinations, an ANalysis Of Variance (ANOVA) was used.

The larger effect size of factor X1 (slag) at two days than at the other two ages is striking. Also, the larger effect size of factor X3 (fineness) at 28 days than at early ages is prominent, whereas the effect size is nearly null. With regard to factor $\mathrm{X} 2$, the only remarkable fact is the similar effect size recorded from two to 28 days. Average effects are shown in Figure 4.

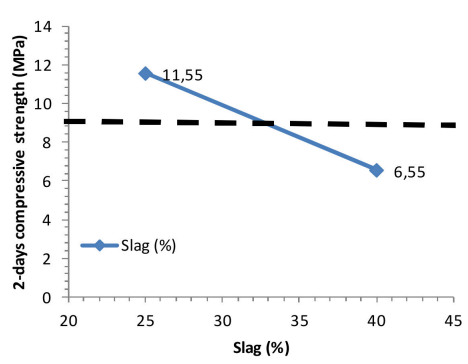

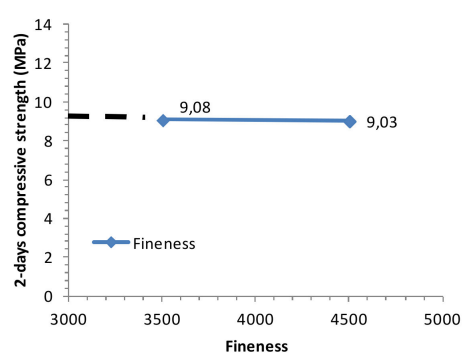

Figure 4. Cont. 

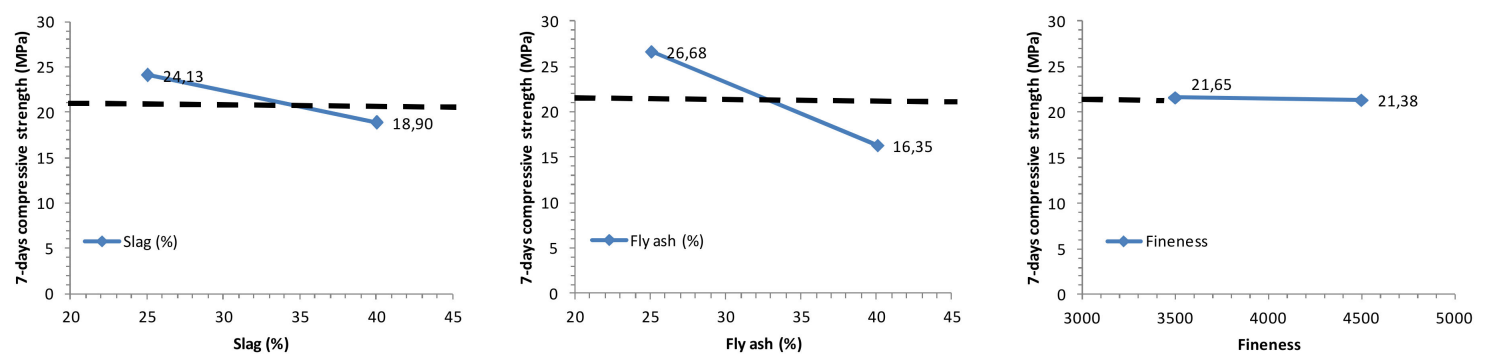

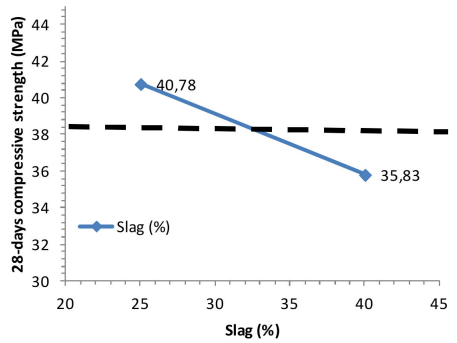

(a)

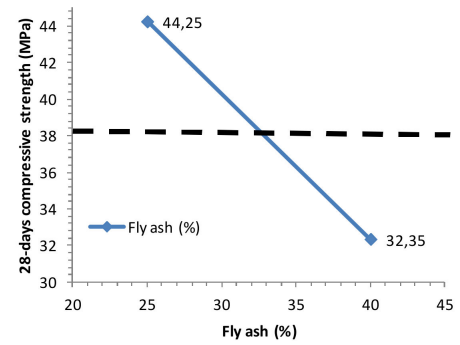

(b)

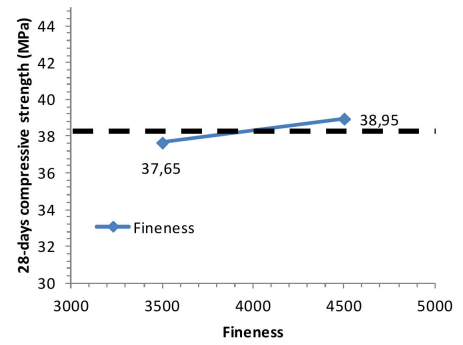

(c)

Figure 4. Average effects for compressive strength results at 2, 7, and 28 days, for slag (a), fly ash (b), and fineness (c).

\subsection{Interaction Effects}

Once the average and main effects for each factor have been assessed, the interactions between all the three factors must be calculated. An interaction would take place when one factor influences the compressive strength results diversely depending on a second factor. Given that, interaction effects for all the factor combinations were calculated. For instance, to assess the X1-X2 interaction effects, the average of factors X1 and X2 at the low level, $(44.8+47.7) / 2=46.25$, and at the high level $(28.6+30.2) / 2=29.4$ were calculated.

In order to get the average value for each of the levels of $X 1 X 3$ and $X 2 X 3$, the same procedure was followed. This experimental design has eight runs or observations and eight $\mathrm{X} 1 \mathrm{X} 2 \mathrm{X} 3$ interaction levels, as shown in Table 5.

Table 5. X1, X2, X3 interaction effects setup and results.

\begin{tabular}{ccccccccc}
\hline \multirow{2}{*}{ Run } & \multicolumn{7}{c}{ Effect Matrix } \\
\cline { 2 - 9 } & Average & X1 & X2 & X3 & X1X2 & X1X3 & X2X3 & X1X2X3 \\
\hline 1 & + & - & - & - & + & + & + & - \\
2 & + & + & - & - & - & - & + & + \\
3 & + & - & + & - & - & + & - & + \\
4 & + & + & + & - & + & - & - & - \\
5 & + & - & - & + & + & - & - & + \\
6 & + & + & - & + & - & + & - & - \\
7 & + & - & + & + & - & - & + & - \\
8 & + & + & + & + & + & + & + & + \\
\hline 2-days comp. strength & 9.05 & -5 & -5.5 & -0.05 & 0.70 & 0.35 & -0.25 & -0.15 \\
\hline 7-days comp. strength & 21.51 & -5.22 & -10.32 & -0.28 & 0.33 & -0.03 & -0.03 & 0.53 \\
\hline 28-days comp. strength & 38.3 & -4.95 & -11.9 & 1.3 & -0.95 & -0.55 & -0.1 & 0.95 \\
\hline
\end{tabular}

Note: Interaction effects: Average $=(+\mathrm{y} 1+\mathrm{y} 2+\mathrm{y} 3+\mathrm{y} 4+\mathrm{y} 5+\mathrm{y} 6+\mathrm{y} 7+\mathrm{y} 8) / 8 ; \mathrm{X} 1=(-\mathrm{y} 1+\mathrm{y} 2-\mathrm{y} 3+\mathrm{y} 4-\mathrm{y} 5+\mathrm{y} 6$ $-\mathrm{y} 7+\mathrm{y} 8) / 4 ; \mathrm{X} 2=(-\mathrm{y} 1-\mathrm{y} 2+\mathrm{y} 3+\mathrm{y} 4-\mathrm{y} 5-\mathrm{y} 6+\mathrm{y} 7+\mathrm{y} 8) / 4 ; \mathrm{X} 3=(-\mathrm{y} 1-\mathrm{y} 2-\mathrm{y} 3-\mathrm{y} 4+\mathrm{y} 5+\mathrm{y} 6+\mathrm{y} 7+\mathrm{y} 8) / 4 ;$ $\mathrm{X} 1 \mathrm{X} 2=(+\mathrm{y} 1-\mathrm{y} 2-\mathrm{y} 3+\mathrm{y} 4+\mathrm{y} 5-\mathrm{y} 6-\mathrm{y} 7+\mathrm{y} 8) / 4 ; \mathrm{X} 1 \mathrm{X} 3=(+\mathrm{y} 1-\mathrm{y} 2+\mathrm{y} 3-\mathrm{y} 4-\mathrm{y} 5+\mathrm{y} 6-\mathrm{y} 7+\mathrm{y} 8) / 4 ; \mathrm{X} 2 \mathrm{X} 3=(+$ $y 1+y 2-y 3-y 4-y 5-y 6+y 7+y 8) / 4 ; X 1 X 2 X 3=(-y 1+y 2+y 3-y 4+y 5-y 6-y 7+y 8) / 4$. 
The effect size was determined by subtracting the average from the partial fit, which is the effect of all the factors. Given that, such partial fits are the Grand Mean for the main effects. Therefore, the $\mathrm{X} 1 \mathrm{X} 2$ effect is given by Equation (1):

$$
\text { X1X2 effect }=\text { X1X2Avg. }- \text { effect of X1 + effect of X2 + Grand Mean }
$$

Figure 5 provides the 2-way effects or interactions for all the three factors. Therefore, it shows the most influential factors and the impact of each factor combination. To visualize these effects, the $Y$ axis is always the same for each combination of factors. The more different the slope, the more influence the interaction effect has on the compressive strength result. In Figure 5, all the lines are nearly parallel at two and seven days; therefore, it can be seen that there is not a clear interaction between the three factors with regard to the compressive strength at early ages. By contrast, all the three factors interact slightly in the 28-days compressive strength outcome. In this case, it is critical to identify how these factors interact in affecting the 28-days compressive strength results. As expected, the X1X2 (slag-fly ash) interaction effect is the largest, followed by the X1X3 (slag-fineness) and X2X3 (fly ash-fineness) interaction effects.
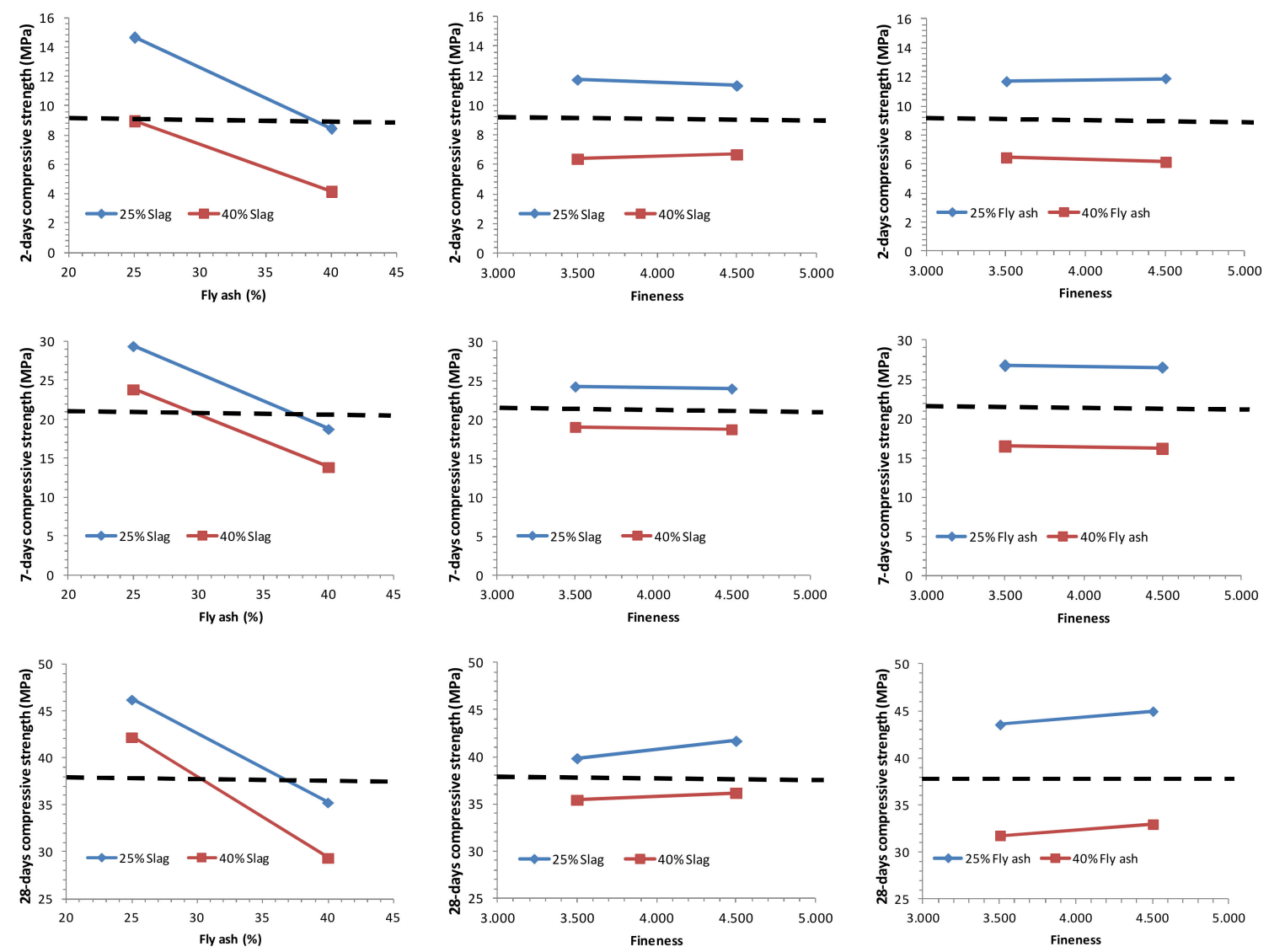

(a)

(b)

(c)

Figure 5. Interaction plots for compressive strength at two- (top), seven- (middle) and 28-days (bottom), for fly ash (a) and fineness $(\mathbf{b}, \mathbf{c})$. 
Finally, for three-way interactions, the effect size was calculated by simply subtracting the partial fit from the corresponding average. For instance, the $\mathrm{X} 1 \mathrm{X} 2 \mathrm{X} 3$ effect when $\mathrm{X} 1$ and $\mathrm{X} 2$ levels are high and $\mathrm{X} 3$ level is low $(\mathrm{X} 1+\mathrm{X} 2+\mathrm{X} 3-)$ was calculated by using Equation (2):

Effect of $(X 1+X 2+X 3-)=(X 1+X 2+X 3-)$ Avg.- (effect of $X 1+$ effect of $X 2+$ effect of $X 3$

+ effect of X1X2 + effect of X1X3 + effect of X2X3 + Grand Mean

\subsection{ANalysis Of Variance (ANOVA)}

ANalysis Of Variance (ANOVA) is the statistical technique which consists of simultaneous hypothesis tests to assess if any of the effects are significant. For each main factor and interaction, some determinations have been performed (Table 6) [22]. The results display that there is one significant parameter, $\mathrm{X} 2$ (amount of fly ash), at 2, 7 and 28 days, but only X1 (amount of slag) at 28 days. This fact is a consequence of the well-known pozzolanicity of fly ash and GGBFS, which starts at older ages. The probability of observing an F-value that is at least as large as the F-value our study obtained is assessed. This probability is low enough to reject the null hypothesis using the common significance level of 0.05 for X2 at 28-days and 7-days, and for X1 and X2 at 2-days. We can conclude that not all the group means are equal. In addition, $\mathrm{p}$-values evaluate how well the sample measures support the argument that the null hypothesis is true. Furthermore, $p$-values only address how likely the data outcomes are, assuming a true null hypothesis, and they do not support the alternative hypothesis. Accordingly, the $p$-value, or statistical significance, does not measure the size of an effect and in itself does not provide a good measure of evidence regarding a model.

Table 6. ANalysis Of Variance (ANOVA).

\begin{tabular}{|c|c|c|c|c|c|c|c|}
\hline SOURCE & DF & SS & MS & F & $p$-Value & F-Critical Value & Remark \\
\hline \multicolumn{8}{|l|}{ 28-days } \\
\hline $\mathrm{X} 1$ & 1 & 49.005 & 49.005 & 27.15 & 0.105 & 161 & Not significant \\
\hline $\mathrm{X} 2$ & 1 & 283.220 & 283.220 & 156.91 & 0.139 & 161 & Significant \\
\hline X3 & 1 & 3.380 & 3.380 & 1.87 & 0.177 & 161 & Not significant \\
\hline $\mathrm{X} 1 \times \mathrm{X} 2$ & 1 & 1.805 & 1.805 & 1.00 & 0.374 & 161 & Not significant \\
\hline $\mathrm{X} 1 \times \mathrm{X} 3$ & 1 & 0.605 & 0.605 & 0.34 & 0.705 & 161 & Not significant \\
\hline $\mathrm{X} 2 \times \mathrm{X} 3$ & 1 & 0.020 & 0.020 & 0.01 & 0.500 & 161 & Not significant \\
\hline Error & 1 & 1.805 & 1.805 & & & & \\
\hline Total & 7 & 339.84 & & & & & \\
\hline \multicolumn{8}{|l|}{ 7-days } \\
\hline $\mathrm{X} 1$ & 1 & 54.601 & 54.603 & 99.05 & 0.105 & 161 & Not significant \\
\hline $\mathrm{X} 2$ & 1 & 213.211 & 213.211 & 386.78 & 0.139 & 161 & Significant \\
\hline $\mathrm{X} 3$ & 1 & 0.151 & 0.151 & 0.27 & 0.177 & 161 & Not significant \\
\hline $\mathrm{X} 1 \times \mathrm{X} 2$ & 1 & 0.211 & 0.211 & 0.38 & 0,374 & 161 & Not significant \\
\hline $\mathrm{X} 1 \times \mathrm{X} 3$ & 1 & 0.001 & 0.001 & 0.00 & 0.705 & 161 & Not significant \\
\hline $\mathrm{X} 2 \times \mathrm{X} 3$ & 1 & 0.001 & 0.001 & 0.00 & 0.500 & 161 & Not significant \\
\hline Error & 1 & 0.551 & 0.551 & & & & \\
\hline Total & 7 & 268.73 & & & & & \\
\hline \multicolumn{8}{|l|}{ 2-days } \\
\hline $\mathrm{X} 1$ & 1 & 50.00 & 50.00 & 1111.1 & 0.105 & 161 & Significant \\
\hline $\mathrm{X} 2$ & 1 & 60.50 & 60.50 & 1344.4 & 0.139 & 161 & Significant \\
\hline $\mathrm{X} 3$ & 1 & 0.005 & 0.005 & 0.11 & 0.177 & 161 & Not significant \\
\hline $\mathrm{X} 1 \times \mathrm{X} 2$ & 1 & 0.980 & 0.98 & 21.78 & 0.374 & 161 & Not significant \\
\hline $\mathrm{X} 1 \times \mathrm{X} 3$ & 1 & 0.245 & 0.25 & 5.44 & 0.705 & 161 & Not significant \\
\hline $\mathrm{X} 2 \times \mathrm{X} 3$ & 1 & 0.125 & 0.13 & 2.78 & 0.500 & 161 & Not significant \\
\hline Error & 1 & 0.045 & 0.05 & & & & \\
\hline Total & 7 & 111.90 & & & & & \\
\hline
\end{tabular}




\subsection{Modeling Approach}

Three polynomial regression equations were obtained by using a central composite factorial design. They can be used to assess the factor interactions. Then, it is possible to identify the significant factors in the regression model. The ANalysis Of Variance (ANOVA) for the fitted equations shown in Table 7 provides the performance of the factorial design. The results of this analysis demonstrated that the equations adequately estimated the response and significant variables relationship. The factorial design is normally utilized for fitting the second order equation by the regression method (Equation (3)).

$$
\text { Compressive strength }(\mathrm{MPa})=\beta_{0}+\sum_{i=1}^{n} \beta_{i} x_{i}+\left(\sum_{i=1}^{n} \beta_{i} x_{i}\right)^{2}+\left(\sum_{i=1}^{n-1} \sum_{j=i+1}^{n} \beta_{i j} x_{i} x_{j}\right)
$$

where $\beta_{0}$ is the constant term and $\beta_{i}$ is the linear effect of the input factor $x_{i}$ (slope). Then, the rest of the terms $\beta_{\mathrm{ij}}$ are the linear by linear interaction effects corresponding to the factor $x_{i}$ and $x_{j}$. The result achieved with the empirical model considering the significant parameters for 2, 7 and 28-days compressive strength is shown in Equations (4)-(6), respectively, and Figure 6. Their coefficients of determination, $R^{2}$, were $0.9960,0.9996$ and 0.9993 for two, seven and 28 days, respectively.

2-days compressive strength $=31.98-0.33 \mathrm{~S}-0.37 \mathrm{~V}-0.000044$ fineness

7 -days compressive strength $==56.18-0.348 \mathrm{~S}-0.688 \mathrm{~V}-0.00024$ fineness

28 -days compressive strength $=70.18-0.33 \mathrm{~S}-0.79 \mathrm{~V}+0.00114$ fineness

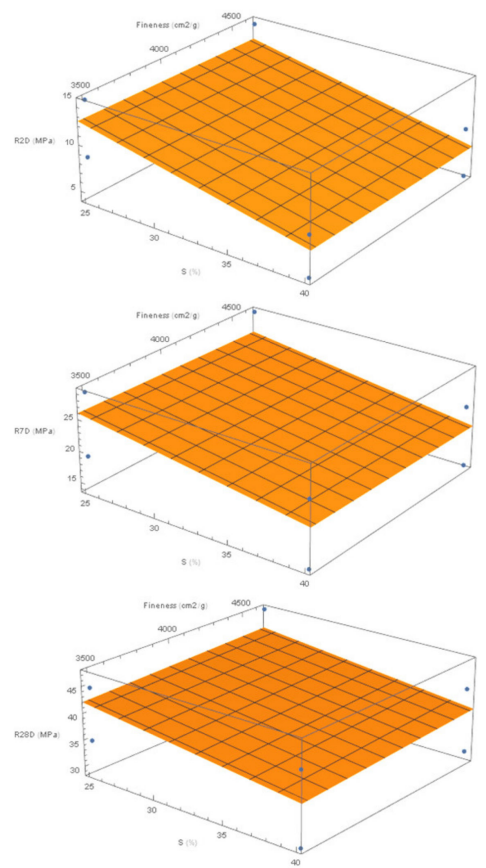

(a)

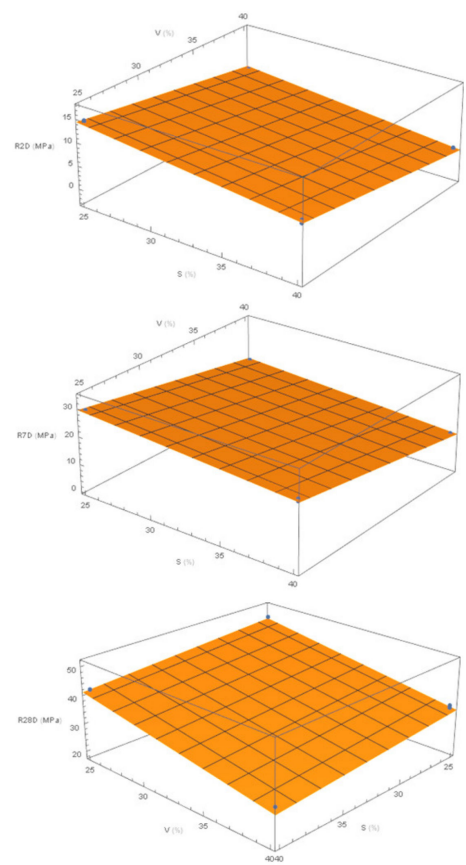

(b)

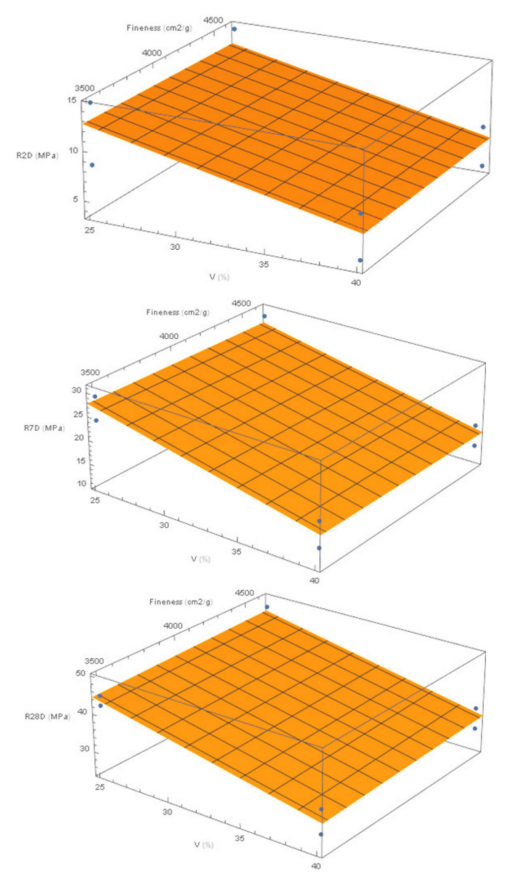

(c)

Figure 6. Three-dimensional response surface plot for compressive strength at 2, 7, and 28 days: (a) blast-furnace slag-fineness; (b) blast-furnace slag-coal fly ash; (c) coal fly ash-fineness. 
Table 7. The ANalysis Of Variance (ANOVA) for the fitted equations.

\begin{tabular}{cccccc}
\hline Equation & Coefficient & Estimate & Standard Error & $t$-Statistic & $p$-Value \\
\hline \multirow{5}{*}{ Equation (7) } & $\mathrm{a} 1$ & 31.98 & 1.97 & 16.22 & 0.000085 \\
& $\mathrm{~b} 1$ & -0.33 & 0.03 & -11.97 & 0.00028 \\
& $\mathrm{c} 1$ & -0.37 & 0.03 & -13.17 & 0.00019 \\
& $\mathrm{~d} 1$ & -0.000044 & 0.0004 & -0.12 & 0.91 \\
Equation (8) & $\mathrm{a} 1$ & 56.18 & 1.46 & 38.48 & 0.0000027 \\
& $\mathrm{~b} 1$ & -0.348 & 0.02 & -16.90 & 0.000072 \\
& $\mathrm{c} 1$ & -0.688 & 0.02 & -33.39 & 0.0000048 \\
Equation (9) & $\mathrm{d} 1$ & -0.00024 & 0.003 & -0.89 & 0.4241 \\
& $\mathrm{a} 1$ & 70.18 & 3.44 & 20.43 & 0.000034 \\
& $\mathrm{~b} 1$ & -0.33 & 0.05 & -6.80 & 0.0024 \\
& $\mathrm{c} 1$ & -0.79 & 0.05 & -16.36 & 0.000082 \\
\hline
\end{tabular}

\section{Conclusions}

Ternary cement is one that contains Portland cement clinker and two other cement constituents in the cement. This paper reports the statistical synergetic effects of the interaction between clinker-blast-furnace slag-coal fly ash on the compressive strength development (two, seven and 28 days) of Portland cement mortars. The present approach is based on a factorial experiment design. It has been observed that mortars made with ternary cements, up to $45 \%$ of coal fly ash and $45 \%$ of ground granulated blast-furnace slag, show a good performance regarding compressive strength at 28 days. However, at early ages (two and seven days), no synergic effect has been recorded. This is due to the slow pozzolanic reaction of both additions. In particular, the compressive strength gain of the ground granulated blast-furnace slag is quite high at later ages. The statistical study revealed a slight interaction of fineness and amount of fly ash and slag after 28 days; whereas at early ages, no synergistic action was detected. A proportion for cement:slag:fly ash of 50:25:25 yielded marked improvements on 2-, 7- and 28-days compressive strength in comparison with 35:40:25 and 35:25:40 compressive strength. Synergistic action in the ternary cements improved the long-term compressive strength of the mortars and yielded a better performance of the mortar that was attributed to a denser microstructure. Finally, three predictive models to estimate the 2-, 7- and 28-days compressive strength have been obtained from the constituent proportions data:

$$
\begin{aligned}
& \text { 2-days compressive strength }=31.98-0.33 \mathrm{~S}-0.37 \mathrm{~V}-0.000044 \text { fineness } \\
& \text { 7-days compressive strength }==56.18-0.348 \mathrm{~S}-0.688 \mathrm{~V}-0.00024 \text { fineness } \\
& \text { 28-days compressive strength }=70.18-0.33 \mathrm{~S}-0.79 \mathrm{~V}+0.00114 \text { fineness }
\end{aligned}
$$

Their coefficients of determination, $\mathrm{R}^{2}$, were higher than 0.99 . Therefore, they are suitable for the tested ternary cements. Compressive strength predictions will have a positive impact on the proper use of the ternary cements depending on the final applications.

Author Contributions: Conceptualization, R.A.R. and D.A.M.; Data curation, R.A.R. and M.Á.S.; Formal analysis, M.Á.S. and D.A.M.; Funding acquisition, D.A.M.; Investigation, R.A.R.; Methodology, R.A.R. and M.Á.S.; Project administration, D.A.M.; Resources, R.A.R. and D.A.M.; Software, R.A.R. and M.Á.S.; Supervision, M.Á.S. and D.A.M.; Validation, M.Á.S.; Visualization, R.A.R.; Writing—original draft, R.A.R.; Writing—review \& editing, R.A.R., M.Á.S. and D.A.M. All authors have read and agreed to the published version of the manuscript.

Funding: This work has been funded through Fundación Gómez Pardo (grant number FGP-11112010), and also benefited from support through the LOEMCO (Universidad Politécnica de Madrid, UPM), a Special Research Centre of the Technical University of Madrid. 
Acknowledgments: The authors would like to acknowledge Guillermina Blázquez for conducting some of the mechanical strength tests and Javier Sanchez, IETcc, for helping with the graphs. The authors also thank Cementos Tudela Veguín, S.A. for supplying the raw materials for this research program.

Conflicts of Interest: The authors declare no conflict of interest.

\section{References}

1. Communication: 2030 Climate Target Plan. Available online: https://ec.europa.eu/info/law/ better\$-\$regulation/have\$-\$your\$-\$say/initiatives/12265\$-\$2030\$-\$Climate\$-\$Target\$-\$Plan (accessed on 30 March 2020).

2. The European Cement Association (CEMBUREAU). Activity Report, 1st ed.; Cembureau: Brussels, Belgium, 2018; pp. 1-56. Available online: https:/cembureau.eu/media/1818/actvity\$-\$report\$-\$2018.pdf (accessed on 22 January 2020).

3. Damtoft, J.S.; Lukasik, J.; Herfort, D.; Sorrentino, D.; Gartner, E. Sustainable development and climate change initiatives. Cem. Concr. Res. 2008, 38, 115-127. [CrossRef]

4. OECD; International Energy Agency (IEA); World Business Council for Sustainable Development (WBCSD). Cement Technology Roadmap 2009_Carbon Emissions Reductions up to 2050, 1st ed.; IEA: Paris, France, 2009; pp. 1-36.

5. European Committee for Standardization (CEN). EN 197-1:2011. Cement_Part 1: Composition, Specifications and Conformity Criteria for Common Cement; European Committee for Standardization (CEN): Brussels, Belgium, 2011.

6. European Committee for Standardization (CEN). EN 197-5:2020. Cement_Part 5: Composition, Specifications and Conformity Criteria for Portland-Composite Cement and Composite Cement; European Committee for Standardization (CEN): Brussels, Belgium, 2020.

7. The European Cement Association (CEMBUREAU). Cements for a Low-Carbon Europe, 1st ed.; Cembureau: Brussels, Belgium, 2012; pp. 1-28.

8. OECD; International Energy Agency (IEA); World Business Council for Sustainable Development (WBCSD). Technology Roadmap: Low-Carbon Transition in the Cement Industry, 1st ed.; IEA: Paris, France, 2018; pp. 1-66.

9. Menéndez, G.; Bonavetti, V.; Irassar, E.F. Strength development of ternary blended cement with limestone filler and blast-furnace slag. Cem. Concr. Compos. 2003, 25, 61-67. [CrossRef]

10. Courard, L.; Michel, F. Limestone fillers cement based composites: Effects of blast furnace slags on fresh and hardened properties. Constr. Build. Mater. 2014, 51, 439-445. [CrossRef]

11. Arora, A.; Sant, G.; Neithalath, N. Ternary blends containing slag and interground/blended limestone: Hydration, strength, and pore structure. Constr. Build. Mater. 2016, 102, 113-124. [CrossRef]

12. Menéndez, G.; Bonavetti, V.L.; Irassar, E.F. Ternary blended cement concrete. Part I: Early age properties and mechanical strength. Mater. Construcc. 2006, 56, 55-67. [CrossRef]

13. Menéndez, G.; Bonavetti, V.L.; Irassar, E.F. Concretes with ternary composite cements. Part III: Multicriteria optimization. Mater. Construcc. 2007, 57, 19-28. [CrossRef]

14. Gao, Y.; De Schutter, G.; Ye, G.; Yu, Z.; Tan, Z.; Wu, K. A microscopic study on ternary blended cement based composites. Constr. Build. Mater. 2013, 46, 28-38. [CrossRef]

15. De Weerdt, K.; Kjellsen, K.O.; Sellevold, E.J.; Justnes, H. Synergy between fly ash and limestone powder in ternary cements. Cem. Concr. Compos. 2011, 33, 30-38. [CrossRef]

16. De Weerdt, K.; Haha, M.B.; Le Saout, G.; Kjellsen, K.; Justnes, H.; Lothenbach, B. Hydration mechanisms of ternary Portland cements containing limestone powder and fly ash. Cem. Concr. Res. 2011, 41, $279-291$. [CrossRef]

17. Ghiasvand, E.; Ramezanianpour, A.A. Effect of grinding method and particle size distribution on long term properties of binary and ternary cements. Constr. Build. Mater. 2017, 134, 75-82. [CrossRef]

18. Antoni, M.; Rossen, J.; Martirena, F.; Scrivener, K. Cement substitution by a combination of metakaolin and limestone. Cem. Concr. Res. 2012, 42, 1579-1589. [CrossRef]

19. Bingöl, F.; Tohumcu, I. Effects of different curing regimes on the compressive strength properties of self compacting concrete incorporating fly ash and silica fume. Mater. Design 2013, 51, 12-18. [CrossRef]

20. Wongkeo, W.; Thongsanitgarn, P.; Ngamjarurojana, A.; Chaipanich, A. Compressive strength and chloride resistance of self-compacting concrete containing high level fly ash and silica fume. Mater. Design 2014, 64, 261-269. [CrossRef] 
21. Kwan, K.H.; Wong, H.H.C. Packing density of cementitious materials: Part 2-Packing and flow of OPC + PFA + CSF. Mater. Construcc. 2008, 41,773-784. [CrossRef]

22. Nehdi, M.L.; Sumner, J. Optimization of ternary cementitious mortar blends using factorial experimental plans. Mater. Struct. 2002, 35, 495-503. [CrossRef]

23. Bonavetti, V.L.; Castellano, C.; Donza, H.; Rahhal, V.F.; Irassar, E.F. Cement with silica fume and granulated blast-furnace slag: Strength behavior and hydration. Mater. Construcc. 2014, 64, e025. [CrossRef]

24. Kashani, A.; San Nicolas, R.; Qiao, G.G.; van Deventer, J.S.J.; Provis, J.L. Modelling the yield stress of ternary cement-slag-fly ash pastes based on particle size distribution. Powder Technol. 2014, 266, 203-209. [CrossRef]

25. Douglas, E.; Pouskouleli, G. Prediction of compressive strength of mortars made with portland cement-blast-furnace slag-fly ash blends. Cem. Concr. Res. 1991, 21, 523-534. [CrossRef]

26. Wang, D.; Chen, Z. On predicting compressive strengths of mortars with ternary blends of cement, GGBFS and fly ash. Cem. Concr. Res. 1997, 27, 487-493. [CrossRef]

27. Erdem, T.K.; Kirca, O. Use of binary and ternary blends in high strength concrete. Constr. Build. Mater. 2008, 22, 1477-1483. [CrossRef]

28. Fernandez, Á.; García Calvo, J.L.; Alonso, M.C. Ordinary Portland Cement composition for the optimization of the synergies of supplementary cementitious materials of ternary binders in hydration processes. Cem. Concr. Compos. 2018, 89, 238-250. [CrossRef]

29. Gesoğlu, M.; Güneyisi, E.; Özbay, E. Properties of self-compacting concretes made with binary, ternary, and quaternary cementitious blends of fly ash, blast furnace slag, and silica fume. Constr. Build. Mater. 2009, 23, 1847-1854. [CrossRef]

30. Mounanga, P.; Khokhar, M.I.A.; El Hachem, R.; Loukili, A. Improvement of the early-age reactivity of fly ash and blast furnace slag cementitious systems using limestone filler. Mater. Struct. 2011, 44, 437-453. [CrossRef]

31. Alonso, M.C.; Garcia Calvo, J.L.; Sanchez, M.; Fernández, A. Ternary mixes with high mineral additions contents and corrosion related properties. Mater. Corrosion 2012, 63, 1078-1086. [CrossRef]

32. Tan, K.; Pu, X. Strengthening effects of finely ground fly ash, granulated blast furnace slag, and their combination. Cem. Concr. Res. 1998, 28, 1819-1825. [CrossRef]

33. Li, G.; Zhao, X. Properties of concrete incorporating fly ash and ground granulated blast-furnace slag. Cem. Concr. Comp. 2003, 25, 293-299. [CrossRef]

34. Jeong, Y.; Park, H.; Jun, Y.; Jeong, J.-H.; Oh, J.E. Microstructural verification of the strength performance of ternary blended cement systems with high volumes of fly ash and GGBFS. Constr. Build. Mater. 2015, 95, 96-107. [CrossRef]

35. Makhloufi, Z.; Chettih, M.; Bederina, M.; Hadj Kadri, E.1.; Bouhicha, M. Effect of quaternary cementitious systems containing limestone, blast furnace slag and natural pozzolan on mechanical behavior of limestone mortars. Constr. Build. Mater. 2015, 95, 647-657. [CrossRef]

36. Hossack, M.; Thomas, M.D.A. Varying fly ash and slag contents in Portland limestone cement mortars exposed to external sulfates. Constr. Build. Mater. 2015, 78, 333-341. [CrossRef]

37. European Committee for Standardization (CEN). EN 1992-1-1. Eurocode 2: Design of Concrete Structures-Part 1-1: General Rules and Rules for Buildings; European Committee for Standardization (CEN): Brussels, Belgium, 2004.

(C) 2020 by the authors. Licensee MDPI, Basel, Switzerland. This article is an open access article distributed under the terms and conditions of the Creative Commons Attribution (CC BY) license (http://creativecommons.org/licenses/by/4.0/). 